\title{
TINDAK PIDANA PROSTITUSI DENGAN MENGGUNAKAN TRANSAKSI VIA MEDIA SOSIAL ELEKTRONIK DALAM PERSPEKTIF TEORI ANOMI ROBERT KING MERTON
}

\author{
Oleh
}

Siti Humulhaer*)

shumulhaer@unis.ac.id

\section{Abstrak}

Prostitusi atau pelacuran merupakan salah satu masalah sosial yang kompleks, mengingat prostitusi merupakan peradaban yang termasuk tertua di dunia dan hingga saat ini masih terus ada pada masyarakat kita. Ditinjau dari beberapa faktor penyebab seseorang melakukan tindak pidana prostitusi, sebagian besar terletak pada faktor ekonomi dan faktor sosial, faktor ekonomi dipengaruhi oleh kondisi lingkungan, suasana lingkungan maupun pendidikan seseorang. Jadi prostitusi terjadi akibat kurangnya "kesejahteraan lahir batin" tidak terlepas dari aspek kehidupan atau penghidupan manusia termasuk rasa aman dan tentram yang dapat dicapai jika kesadaran masyarakat terhadap kewajiban penghargaan hak orang lain telah dipahami dan dihayati sehingga penegakan hukum dan keadilan berdasarkan kebenaran yang telah merupakan kebutuhan sesama, kebutuhan seluruh masyarakat. Adapun upaya penanggulangannya adalah dengan meningkatkan keimanan dan ketakwaan kepada Yang Maha Esa melalui pendidikan agama, melalui kegiatan religius dan pemahaman tentang ilmu-ilmu keagamaan. Menyediakan lembaga-lembaga baik formal maupun non formal untuk menciptakan suatu kegiatan yang positif untuk menunjang dalam hal perekonomian, Memberikan penyuluhan kepada masyarakat tentang aturan hukum dan sanksi hukum terhadap seseorang yang melakukan tindak pidana prostitusi dengan menggunakan transaksi via media sosial elektronik, Penegakan hukum yang tegas dalam upaya menanggulangi tindak pidana prostitusi dengan menggunakan transaksi via media sosial elektronik.

\section{Kata Kunci : Tindak Pidana Prostitusi, Media Sosial Elektronik}

\section{A.PENDAHULUAN}

Prostitusi atau pelacuran merupakan salah satu masalah sosial yang kompleks, mengingat prostitusi merupakan peradaban yang termasuk tertua di dunia dan hingga saat ini masih terus ada pada masyarakat kita ${ }^{1}$. Ditinjau dari beberapa faktor penyebab seseorang melakukan

1 Yesmil anwar dan adang, Pembaharuan Hukum Pidana Reformasi Hukum Pidana, Jakarta: PT. Grasindo,2010, hlm 354.

*) Penulis adalah Dosen Fakultas Hukum Universitas Islam Syekh Yusuf tindak pidana prostitusi, sebagian besar terletak pada faktor ekonomi dan faktor sosial, faktor ekonomi dipengaruhi oleh kondisi lingkungan, suasana lingkungan maupun pendidikan seseorang. Jadi prostitusi terjadi akibat kurangnya "kesejahteraan lahir batin" tidak terlepas dari aspek kehidupan atau penghidupan manusia termasuk rasa aman dan tentram yang dapat dicapai jika kesadaran masyarakat terhadap kewajiban penghargaan hak orang lain telah dipahami dan dihayati sehingga penegakan hukum dan 
keadilan berdasarkan kebenaran yang telah merupakan kebutuhan sesama, kebutuhan seluruh masyarakat. 2

Berkaitan dengan prostitusi KUHP mengatur dalam pasal 296 dan pasal 506, KUHP tindak pidana membuat kesengajaan menyebabkan atau memudahkannya dilakukan tindakan-tindakan melanggar kesusilaan denga orang ketiga sebagai mata pencaharian atau sebagai kebiasaan diatur didalam pasal 296 KUHP yang berbunyi :

"Barang siapa dengan sengaja menyebabkan atau memudahkan perbuatan cabul oleh orang lain, dan menjadikan sebagai mata pencaharian atau kebiasaan, diancam dengan pidana penjara paling lama satu tahun empat bulan atau denda paling banyak lima belas ribu rupiah". ${ }^{3}$

Pasal 506 KUHP diatur mengenai tindak pidana sebagai germo atau mucikari yang mengambil keuntungan dari perbuatan melanggar kesusialaan yang dilakukan oleh seorang perempuan atau lakilaki yang berbunyi :

"Barang siapa yang menarik keuntungan dari perbuatan cabul seseorang wanita dan menjadikan seorang pelacur, diancam dengan pidana kurungan paling lama satu tahun."4

Dalam Undang-Undang dan nomor 11 tahun 2008 Tentang Informasi dan Transaksi Elektronik Ada Beberapa Pasal Yang Mengatur Tentang Tindak Pidana Eksploitasi Seksual Komersial yaitu pasal 27 ayat (1), pasal 45 ayat (1) pasal 52 ayat (1) jo. 27 ayat (1)

Pasal 27 ayat (1) berbunyi :

2 Leden Marpaung, Kejahatan Terhadap Kesusilaan dan Masalah Revensinya, Jakarta : Sinar Grafika, 2008, hlm 2.

3 Andi Hamzah, KUHP Dan KUHAP Edisi Revisi, Jakarta : Rineka Cipta 2008, hlm. 119.

4 Ibid, hlm 200.
"Setiap orang dengan sengaja dan tanpa hak mendistribusikan dan/ atau menstransmisikan dan/atau membuat dapat diaksesnya informasi dan transaksi elektronik dan/atau dokumen elektronik yang memiliki muatan elektronik".

Pasal 45 ayat (1) berbunyi :

"Setiap orang memenuhi unsur sebagaimana dimaksud dalam pasal 27 ayat (1), ayat (2), ayat (3), atau ayat (4) dipidana pidana penjara paling lama 6 (enam) tahun dan/atau denda paling banyak Rp. 1.000.000.000,00 (satu miliyar rupiah)".

Pasal 52 ayat (1) jo pasal 27 ayat (1) berbunyi :

"Dalam hal tindak pidana sebagaimana dimasud dalam pasal 27 ayat (1) menyangkut kesusilaan atau ekspolitasi seksual terhadap anak dikenakan pemberatan sepertiga dari pidana pokok".

\section{B. PEMBAHASAN}

Prostituasi online adalah gejala kemasyarakatan dimana seseorang menjual diri, melakukan perbuatan asusila sebagai mata pencaharian dan media sosial sebagai alat untuk membantu bernegosiasi harga dan tempat dilakukannya prostitusi tersebut 5 .

Adapun Pemahaman terhadap Tindak Pidana tidak terlepas dari pemahaman tentang pidana itu sendiri, untuk itu sebelum memahami pengertian tentang tindak pidana, terlebih dahulu harus dipahami tentang pengertian pidana. Istilah pidana tidak terlepas dari masalah pemidanaan. Secara umum pemidanaan merupakan bidang dari pembentukan Undang-undang, karena adanya asas legalitas. Pembentukan undang-undang akan menetapkan perbuatan apa saja yang

5 https//www.Kompasiana.com 
dapat dikenakan pidana dan pidana bagaimanakah yang dapat dikenakan.

Dengan memperhatikan keterkaitan antara suatu tindak pidana dan ketentuan atau undang-undang hukum pidana, maka pengertian pidana haruslah dipahami secara benar, istilah pidana banyak diberikan oleh para ahli, menurut Roeslan Saleh, pidana adalah reaksi atas delik dan ini berwujud suatu nestapa yang dengan sengaja dilimpahkan, Negara kepada pembuat delik, dengan demikian pemidanaan adalah pemberian nestapa dengan sengaja dilakukan oleh Negara kepada pembuat delik. ${ }^{6}$ Dan Strafbaar feit merupakan istilah asli bahasa Belanda yang diterjemahkan ke dalam bahasa Indonesia dengan berbagai arti diantaranya yaitu, tindak pidana, delik, perbuatan pidana, peristiwa pidana maupun perbuatan yang dapat dipidana. Kata Strafbaar feitterdiri dari 3 kata, yakni straf, baar dan feit. Berbagai istilah yang digunakan sebagai terjemahan dari strafbaar feit itu, ternyata straf diterjemahkan sebagai pidana dan hukum.Perkataan baar diterjemahkan dengan dapat dan boleh, sedangkan untuk kata feit diterjemahkan dengan tindak, peristiwa, pelanggaran dan perbuatan.

Menurut Pompe, sebagaimana yang dikemukakan oleh Bambang Poernomo, pengertian strafbaar feit dibedakan menjadi 7 :

a. Defenisi menurut teori memberikan pengertian "strafbaar feit" adalah suatu pelanggaran terhadap norma, yang dilakukan karena kesalahan si pelanggar dan diancam dengan pidana untuk mempertahankan tata hukum dan

\footnotetext{
${ }^{6}$ Andi Hamzah dan Siti Rahayu, Suatu Tinjauan Ringkas Sistem Pemidanaan di Indonesia, Jakarta : Akademika Pressindo, 1983. hlm, 24.

7 Bambang Poernomo, Asas-asas Hukum Pidana, Jakarta : Ghalia Indonesia, hlm. 91
}

menyelamatkan kesejahteraan umum;

b. Definisi menurut hukum positif, merumuskan pengertian "strafbaar feit" adalah suatu kejadiaan (feit) yang oleh peraturan perundang-undangan dirumuskan sebagai perbuatan yang dapat dihukum.

Sejalan dengan definisi atau pengertian menurut teori dan hukum positif di atas, J.E Jonkers juga telah memberikan defenisi strafbaar feit menjadi dua pengertiaan, sebagaimana yang dikemukakan Bambang Pornomo yaitu :

a. Definisi pendek memberikan pengertian "strafbaar feit" adalah suatu kejadian (feit) yang dapat diancam pidana oleh Undang-Undang.

b. Definisi panjang atau lebih dalam memberikan pengertian "strafbaar feit" adalah suatu kelakuan yang melawan hukum berhubung dilakukan dengan sengaja atau alfa oleh orang yang dapt dipertanggungjawabkan.

Menurut definisi pendek pada hakekatnya menyatakan bahwa pastilah untuk setiap delik yang dapat dipidana harus berdasarkan Undang-Undang yang dibuat oleh pembentuk Undang-Undang, dan pendapat umum tidak dapat menentukan lain daripada apa yang telah ditetapkan dalam Undang-undang. Definisi yang panjang lebih menitikberatkan kepada sifat melawan hukum dan pertanggung jawaban yang merupakan unsur-unsur yang telah dirumuskan secara tegas didalam setiap delik, atau unsur yang tersembunyi secara diamdiam dianggap ada. 8

Simons dalam Roni Wiyanto mendefinisikan tindak pidana sebagai suatu perbuatan (handeling) yang diancam de-

8 Roni Wiyanto. Asas-asas Hukum Pidana Indonesia.Bandung: C.V.Mandar Maju. 2012, hlm. 160 . 
ngan pidana oleh undang-undang, bertentangan dengan hukum (onrechtmatig) dilakukan dengan kesalahan (schuld) oleh seseorang yang mampu bertanggungjawab. Rumusan pengertian tindak pidana oleh simons dipandang sebagai rumusan yang lengkap karena akan meliputi :

1. Diancam dengan pidana oleh hukum

2. Bertentangan dengan hukum

3. Dilakukan oleh seseorang dengan kesalahan (schuld)

4. Seseorang itu dipandang bertanggung jawab atas perbuatannya.

Van Hammel juga sependapat dengan rumusan tindak pidana dari simons, tetapi menambahkan adanya "sifat perbuatan yang mempunyai sifat dapat dihukum". Jadi, pengertian tindak pidana menurut Van Hamael meliputi lima unsur, sebagai berikut :

1. Diancam dengan pidana oleh hukum

2. Bertentangan dengan hukum

3. Dilakukan oleh seseorang dengan kesalahan (schuld)

4. Seseorang itu dipandang bertanggung jawab atas perbuatannya.

5. Sifat perbuatan yang mempunyai sifat dapat dihukum.

Dan berdasarkan Teori Anomi menurut (Robert K. Merton)

Teori ini sejalan dengan perspektif disorganisasi sosial $=$ Teori ini berpendapat bahwa : Penyimpangan adalah akibat dari adanya berbagai ketegangan dalam suatu struktur masyarakat tertentu $\rightarrow$ sehingga ada individu-individu yang mengalami tekanan/ketegangan $\rightarrow$ akibatnya menyimpang.

Konsep anomie sebelumnya diperkenalkan oleh Emile Durkheim $\rightarrow$ suicide anomique (akibat dari hilangnya kontrol sosial dan tidak ada norma sosial yang dapat dijadikan pegangan untuk berperilaku conform) Sekelompok masyarakat terpaksa mencapai tujuan-tujuan statusnya melalui cara-cara yang tidak sah $\rightarrow$ termasuk penyimpangan atau tindakan kriminal lainnya.
Fakta yang ada menunjukkan bahwa tindakan menyimpang karena situasi anomie, banyak dilakukan oleh orangorang miskin dan kelas-kelas sosial bawah.

- CONFORMITY: contohnya adalah orang yang berhasil meraih mimpi dengan cara yang halal (american dream)

- RITUALISM: contohnya adalah orangorang yang tekun beribadah tetapi mengabaikan kebutuhan hidup/ duniawinya; atau orang-orang yang bekerja tanpa memahami makna kerjanya (seperti mesin)

- REBELLION: contohnya adalah orangorang yang melakukan pemberontakan atau orang-orang yang menganut garis keras politik radikal

- INNOVATION: contohnya: orang-orang yang melakukan tindakan kriminal: pencuri, perampok, pelacur, dll.

- RETREATISM: contohnya adalah orang-orang yang mengasingkan diri, menarik diri dari pergaulan, orang yang merasa gagal dan kalah $\rightarrow$ orangorang yang kecanduan, ingin bunuh diri, kekacauan mental, dll.

- asumsi teori anomie bahwa penyimpangan adalah fenomena yang universal $\rightarrow$ padahal penyimpangan bersifat relatif, karena tidak sama di berbagai kelompok masyarakat.

- Teori ini bersifat bias kelas

- Penjelasan tentang retreatism $\rightarrow$ terlalu menyederhanakan persoalan.

Contoh : mengenai pelacuran melalui on line

- Pelacuran tidak hanya dilakukan oleh perempuan dewasa, tetapi saat ini mulai banyak anak perempuan (ABG) yang melacur, baik melaui on-line. Walaupun pelacur, mereka adalah perempuan, mereka melakukan itu karena selama ini anggapan masyarakat terutama laki-laki menempatkan perempuan hanya sebagai pemuas atau pelayan seks saja, jadilah 
pelacuran tumbuh subur. Hal ini lebih diperparah lagi dengan mitos keperawanan di masyarakat, padahal korban perkosaan semakin meningkat. Mereka yang menjadi korban perkosaan dan berasal dari ekonomi lemah dengan kesempatan kerja yang kecil banyak yang akan lari ke dunia pelacuran baik secara online ataupun tidak melalui online. Kita tidak bisa menyalahkan mereka para pelacur itu karena sistem di Indonesia justru membuat perempuan terjebak dalam kepelacuran itu sendiri. Dan hal tersebut termasuk ke dalam INNOVATION: contohnya: orang-orang yang melakukan tindakan kriminal: pencuri, perampok, pelacur, dll.

- Faktor-faktor yang maraknya prostitusi atau pelacuran melalui online internet adalah:

Lemahnya tingkat keimanan seseorang terhadap Tuhan Yang Maha Esa. Pada dasarnya, keimanan adalah landasan sseorang dalam menjalani kehidupan ini. Tiap-tiap agama mempunyai aturan sendiri-sendiri mengenai perintah dan larangan Tuhan Y.M.E.

Kemiskinan, kemiskinan telah memaksa banyak keluarga untuk merencanakan strategi penopang kehidupan mereka termasuk menjual moral untuk bekerja.

Keinginan cepat kaya (materialistic), keinginan untuk memiliki materi dan standar hidup yang lebih tinggi-memicu terjadinya pelacuran. Bisnis prostitusi online internet menjadi peluang bisnis yang menghasilkan keuntungan besar.

Lemahnya penegakan hukum, kontrol dan pengawasan terhadap situs-situs internet.

Upaya penanggulangan dengan melihat perkembangan anak-anak dan remaja yang sering mengakses internet dan juga menggunakan sarana facebook sehingga konsep ideal pengaturan UndangUndang Informasi dan Transaksi Elektronik guna menanggulangi anak dan remaja terjun dalam dunia prostitusi melalui sarana chatting juga yang sering diminati para pelaku kejahatan perlu ditambahkan pasal yang mengatur tentang masalah perlindungan anak di internet upaya guna penangulangi anak anak dan pelajar SMP, SMA yang marak terjun dalam dunia prostitusi melalui internet. Pemerintah dapat membuat peraturan yang mewajibkan pemilik internet menggunakan alat filtering untuk memblokir situs terlarang dan patroli cyber dan Upaya penanggulangan ditinjau dari budaya hukumnya dengan cara pencegahan tindak cyberporn melalui pendekatan sosial antara lain dengan memasukkan kurikulum pendidikan internet dan kontrol dari orang tua terhadap anaknya dalam penggunaan internet.

\section{PENUTUP}

\section{Kesimpulan}

Bahwa prostituasi onliane merupan suatu gejala sosial yang ada dimasyarakat sejak dahulu dimana permasalahan ini kian lama semakin berbeda pula modus operandinya, baik dari segi pelakunya maupun media komunikasi dan transasi yang digunakan. Dimana prostitusi online adalah gejala kemasyarakatan dimana seseorang menjual diri, melakukan perbuatan asusila sebagai mata pencaharian dan media sosial sebagai alat untuk membantu bernegosiasi harga dan tempat dilakukannya prostitusi tersebut dan ditinjau dari beberapa faktor penyebab seseorang melakukan tindak pidana prostitusi, sebagian besar terletak pada faktor ekonomi dan faktor sosial, faktor ekonomi dipengaruhi oleh kondisi lingkungan, suasana lingkungan maupun pendidikan seseorang. Jadi prostitusi terjadi akibat kurangnya kesejahteraan lahir batin "kesejahteraan lahir batin" tidak terlepas dari aspek kehidupan atau penghidupan manusia termasuk rasa aman dan 
tentram yang dapat dicapai jika kesadaran masyarakat terhadap kewajiban penghargaan hak orang lain telah dipahami dan dihayati sehingga penegakan hukum dan keadilan berdasarkan kebenaran yang telah merupakan kebutuhan sesama, kebutuhan seluruh masyarakat.

Dan jika dikaitkan dengan teori anomi robert king merton maka suatu tindak pidana prostitusi via media sosial elektronik merupakan suatu perilaku delinkuen dengan tahapan tertentu pada struktur sosial yang akan menimbulkan, melahirkan dan menumbuhkan suatu kondisi terhadap pelanggaran norma masyarakat yang merupakan reaksi normal yang pada akibatnya menimbulkan suatu permasalahan hukum yang tidak dapat dibenarkan baik secara norma budaya dan struktur kemasyarakatan yang ada.

\section{Saran}

Dalam hal ini yang berkaitan dengan upaya-upaya untuk mencegah dan upaya penegakan hukum terhadap tindak pidana prostitusi dengan menggunakan transaksi via media sosial elektronik maka sebaiknya dilakukan hal-hal sebagai berikut :

- Meningkatkan keimanan dan ketakwaan kepada Yang Maha Esa melalui pendidikan agama, melalui kegiatan religius dan pemahaman tentang ilmuilmu keagamaan.

- Menyediakan lembaga-lembaga baik formal maupun non formal untuk menciptakan suatu kegiatan yang positif untuk menunjang dalam hal perekonomian.

- Memberikan penyuluhan kepada masyarakat tentang aturan hukum dan sanksi hukum terhadap seseorang yang melakukan tindak pidana prostitusi dengan menggunakan transaksi via media sosial elektronik.

- Penegakan hukum yang tegas dalam upaya menanggulangi tindak pidana prostitusi dengan menggunakan transaksi via media sosial elektronik.

\section{DAFTAR PUSTAKA}

A. Literatur

Anwar Yesmil dan Adang, Pembaharuan Hukum Pidana Reformasi Hukum Pidana, Jakarta: Grasindo, 2010

Hamzah Andi, KUHP Dan KUHAP Edisi Revisi, Jakarta : Rineka Cipta 2008 dan Rahayu Siti, Suatu Tinjauan Ringkas Sistem Pemidanaan di Indonesia, Jakarta: Akademika Pressindo, 1983

Marpaung, Leden, Kejahatan Terhadap Kesusilaan Dan Masalah Revensinya, Jakarta : Sinar Grafika, 2008

Poernomo Bambang, Asas-asas Hukum Pidana, Jakarta : Ghalia Indonesia

Roni Wiyanto Roni . Asas-asas Hukum Pidana Indonesia.Bandung: Mandar Maju, 2012

\section{B. Perundang-undangan}

Indonesia, Kitab Undang-Undang Hukum Pidana (KUHP)

.........., Undang-Undang dan nomor 11 Tahun 2008 Tentang Informasi dan Transaksi Elektronik

\section{Sumber lain}

https/ /www.Kompasiana.com 